DOI: 10.31866/2617-2674.4.1.2021.235079

UDC 791.22:004.946

\title{
VIRTUAL PRODUCTION: A NEW APPROACH TO FILMMAKING
}

\section{Oleksandr Priadko ${ }^{1 a}$, Maksym Sirenko ${ }^{2 a}$}

${ }^{1}$ Honored Worker of Ukraine Culture, PhD in Technical Sciences, Associate Professor; e-mail: globalfilm2017@gmail.com; ORCID: 0000-0002-9080-6758

${ }_{2}^{2}$ Master's Degree Student at the Cinema and Television Arts Department; e-mail: maksym.sirenko99@gmail.com; ORCID: 0000-0003-0384-368X

${ }^{a}$ Kyiv National University of Culture and Arts, Kyiv, Ukraine

\section{Keywords:}

virtual film production;

film;

technology;

pre-production;

visualization;

cinematography;

visual effects;

augmented reality

\begin{abstract}
The purpose of the research is to investigate the components of virtual production, identify the structure, basic tools of virtual technologies and their benefits, to define differences between virtual processes and traditional filmmaking. The research methodology is based on general scientific methods of complex analysis of the processes that take place in virtual production, and analysis of basic virtual tools, computer programs; use a comparative method for virtual production and traditional film production technology; generalization of the work of virtual technologies, determination of their advantages and disadvantages, research of their influence on modern cinematography. The scientific novelty of the obtained results lies in the systematic analysis of modern virtual technologies components and tools, determined the features of virtual production and its impact on the film industry, proven the relevance and rationality of the use of virtual technologies, both today and in the future. Conclusions. In the course of the research, numerous advantages and new opportunities offered by virtual production were revealed. The essence of virtual processes in film production is analyzed, it is shown how modern computer tools can be creatively applied at each stage of film production. Virtual production is the next logical step in the constant evolution of the film industry, which is changing the film industry today.
\end{abstract}

For citation:

Priadko, O. and Sirenko, M. (2021). Virtual production: a new approach to filmmaking. Bulletin of Kyiv National University of Culture and Arts. Series in Audiovisual Arts and Production, 4(1), pp.52-58.

\section{Problem statement}

Cinematography, as an art and a branch of production, is constantly evolving, at- tracting new ways and tools to amaze the audience again and again. Virtual technologies and programs have long been part of the film industry. A large number of 
films use the tools of virtual programs at one or another stage of production. They open up incredible opportunities for filmmakers and their potential is growing very rapidly. However, film production in the new quality of modern processes of virtual production with its technological features requires some additional research.

\section{Recent research and publications analysis}

The research of Afanaseva V. (2005), Nosov N. (2000) Heim M. (1993) and other scientists played an important role in the study of the phenomenon of virtual reality.

Connections of virtual processes with the field of art, conducting research in the field of aesthetics, semiology, film theory and art, were analyzed by Anisimov O. (2003), Aronson O. (2007), Lotman Y. (1998), Mankovskaya N. (2011), Mihalkovich V. (1986), Mettc K. (2013), Ribo T. (1997) and others.

Among the materials that consider the use of virtual production in various aspects of its implementation, the work of Noah Kadner is worth noting (2019). Bill Desowitz in his publication described some of the benefits of using virtual technology on the example of the movie Gravity. Virtual reality and the process of virtualization of images in modern audiovisual arts and their gradual evolution in the technology of screen painting were studied in detail by Mozhenko M. and Priadko O. (2018) in the work "Virtual reality - from technology to art".

The purpose of the research is to investigate the components of virtual production, identify the structure, basic tools of virtual technologies and their benefits, to define differences between virtual processes and traditional film production.
The scientific novelty of the obtained results lies in the systematic analysis of modern virtual technologies components and tools, determined the features of virtual production and its impact on the film industry, proven the relevance and rationality of the use of virtual technologies, both today and in the future.

\section{Main research material}

Today, the technology of virtual production and its implementation are the basis of new approaches in the creation of films, ensuring the use of a range of computer programs and automated production methods for image visualization. According to the team at Weta Digital (a company that develops digital visual effects for films and television), "Virtual production is where the digital and physical worlds meet" (Kadner, 2019, p.3). Moving Pic ture Company (a company engaged in visual effects and production) adds to this definition with more technical detail: virtual production combines augmented and virtual reality with CGI and game-engine technologies to let members of the film production crew (director, director of photography, producer, actors, etc.) watch their scenes unfold life and see the final result in the process of shooting.

Production virtualization helps to solve the main problems related to traditional film production, to identify "pain points" in technological processes. Many of today's films, especially science fiction and action movies, require an exceedingly complex production process that requires coordinated creative work with the involvement of various technology and science in a short time. The modern process of film production has moved to a nonlinear plane from a linear one, in which the sequence of stages usually includes 
first project development on paper, then pre-production and finally the production and post-production. Director of Gravity movie Alfonso Cuarón, emphasizing the non-linearity of modern film production technology, said that post-production was done before pre-production. Iteration in cinema (the act of improving the process through repeated successive attempts to achieve the desired result) is expensive and complex. Usually, the iteration process in standard production is spent on searching for common ground instead of improving an existing common vision.

For moviemakers, the main problem is uncertainty. When the director of photography has to guess the colour of the lighting so that it matches the invisible element of the green screen, or a director does not know exactly what the virtual character of his film will actually look like, that is uncertainty. The final form of the image acquires in the post-production period when big changes are very expensive in the best case, and impossible due to a coming release deadline in the worst The arrival to a final version of a scene is often a long road involving replacement of temporary or missing shots, colour correction, missing sound, etc. All these aspects make it difficult for filmmakers to achieve the final version of the scene, and the end result is often a film released with some portion of creative compromise.

Virtual production:

- Includes a more iterative, non-linear, and collaborative process.

- Motivates the filmmakers (including studio heads and participants in the entire production process) to collaboratively iterate on visuals at the moment. (visual effects can be assessed directly on the set, no need to wait for the end of post-production).
- Iteration begins much earlier in the production schedule.

- Can create high-quality images at the first stage of filmmaking - pre-production.

- Makes digital content cross-compatible and useful from pre-visualization to final outputs.

Image virtualization is the creation of a specific screen painting conceived by a creative team (director, screenwriter, production designer, director of photography, visual effects supervisor) by using not only a single computer, but also the whole computer system, to which both real and virtual cameras are connected during the filming process. Virtualization can also be defined as a prototype of images created for transmission of creative intentions in a shot, scene, episode. (Mozhenko, 2018).

For directors, the uncertainty of the usual pre-production and visual effects production is replaced by working images close to the end result. Because these high-quality images are created in real time, iteration and experimentation are simplified, more cost-effective, and flexible. The process of movie production becomes comprehensively unifying and connected, the main image and preproduction can be done integrally. "Now we can make a lot more mission-critical decisions earlier in the process because the aesthetics of the renders look a lot better," said Glenn Derry, founder and vice president of visual effects at the Fox VFX Lab (Kadner, 2019, p.59).

In terms of editing, virtual production also reduces uncertainty by offering and providing temporary images much closer to the final look, which helps to eliminate missed or incomplete shots. Creating previous images in real-time offers additional benefits. Shots sequences can be quickly updated and displayed at a very 
high level of image quality. As a result, more members of the film crew can share their vision of the final content much earlier - in the production process. "It's a creative sandbox where everyone can have input," says Harrison Norris, developer and director of film stunts (Kadner, 2019, p.70).

Today, analogue processes for creating combined shots (travelling mattes, infrared screen, front projection, etc.) have been replaced by virtual VFX production using LED screens of large size and various shapes: for example, in the movie Gravity it was a three-dimensional design $6 \times 6 \times 6$ meters (Desowitz, 2013).

Real-time display of images on the LED wall in combination with camera tracking to create the final pictures is a modern stage of virtual movie production. The benefits of "live" images played back on the LED screen against a certain background by actors are huge. Compared to the cinematic process of shooting on a green screen with the use of LED screens, there is no uncertainty in the actions of the cast and crew. Everybody can accurately see all the components of the movie image and how events unfold in real-time. A cameraman can shoot a virtual object just like any real one, and actors can respond not to a marker representing an imaginary picture, but to real images that form a single shot. All the illumination and natural glare emitted by the screen provides important artistic clues and enhances the realism of the images, in contrast to the typical struggle to avoid colour mixing and glare from a traditional green screen. Sam Nicholson, cinematographer and visual effects team leader, emphasizes that this technology is more realistic for actors: It's one thing, for example, to sit in an imaginary train car on a green background, and another allows you to be there in conditions that create virtual production technology. "Everyone feels that they are on a train, and this is a huge help to the actors and the director" (Kadner, 2019, p.79). And image virtualization is not limited to this technology but forms a new virtual computer cinema world with digital or semi-digital characters and the environment.

Virtual production can be used to plan or directly improve images in a variety of movies. Usually, virtual production is more common in films with visual effects, but it can also be used to create a full-fledged image for more traditional films or films without effects. The main films with visual effects of the past decade have increasingly relied on virtual products, and this dependence is growing. Here are some examples of movies that depended heavily on virtual production: The Lord of the Rings, Harry Potter, Jurassic World, Star Wars, Pirates of the Caribbean, Transformers, Avatar and many others. Even films that have no special effects are largely released through virtual production. These are the movies that use virtual production to show a situation with truth or an impossible situation, for example: Life of Pi, Logan, Bohemian Rhapsody, etc. (Mozhenko, 2018).

Film production is constantly evolving from both a technical and a creative point of view. It is enough to compare silent films, for example, with the film Avatar, to see this progress fairly well. Although they are very different in craft and subject matter, these two extremes have a common goal of bringing to the viewer a good, professionally created story. Virtual production and the benefits it offers to moviemaking is the next logical step in the constant evolution of cinematography. 


\section{Conclusions}

In the course of the research, numerous advantages and new opportunities offered by virtual production have been revealed. The essence of virtual processes in film production is analyzed, it is shown how modern computer tools can be creatively applied at each stage of film production. Virtual production is the next logical step in the constant evolution of the film industry, and it is changing the film industry today. Virtual production becomes necessary for every cinematographer, whether it is a producer who wants to use its potential for business or a director and cameraman who want to creatively use virtual tools.

\section{REFERENCES}

Afanaseva, V.V., 2005. Totalnost virtualnogo [The totality of the virtual]. Saratov: Nauchnaia kniga.

Anisimov, O.S., 2003. Virtualnye osobennosti igromodelirovaniia [Virtual features of game modeling]. Moscow: Put.

Aronson, O.V., 2007. Kommunikativnyi obraz (Kino. Literatura. Filosofiia) [Communicative image (Cinema. Literature. Philosophy)]. Moscow: Novoe literaturnoe obozrenie.

Desowitz, B., 2013. Reverse Engineering 'Gravity'. Animation World Network. [online] Available at: $<$ https://www.awn.com/vfxworld/reverse-engineering-gravity> [Accessed 02 April 2021]. Heim, M., 1993. The Metaphysics of Virtual Reality. New York: Oxford University Press.

Kadner, N., 2019. The Virtual Production Field Guide. [online] Available at: <https://cdn2. unrealengine.com/Unreal+Engine\%2Fvpfieldguide\%2FVP-Field-Guide-V1.2.02-5d28ccec9909 ff626e42c619bcbe8ed2bf83138d.pdf> [Accessed 02 April 2021].

Lotman, lu.M., 1998. Ob iskusstve [About art]. St. Petersburg: Iskusstvo.

Mankovskaia, N.B. and Bychkov, V.V., 2011. Sovremennoe iskusstvo kak fenomen tekhnogennoi tcivilizatcii [Contemporary art as a phenomenon of technogenic civilization]. Moscow: Russian State University of Cinematography named after S. Gerasimov.

Mettc, K., 2013. Voobrazhaemoe oznachaiushchee. Psikhoanaliz i kino [Imaginary signifier. Psychoanalysis and cinema]. Translated from French by D. Kalugin and N. Movnina. St. Petersburg: Izdatelstvo Evropeiskogo universiteta v Sankt-Peterburge.

Mikhalkovich, V.I., 1986. Izobrazitelnyi iazyk sredstv massovoi kommunikatcii [The visual language of mass communication]. Moscow: Nauka.

Mozhenko, M.V. and Priadko, O.M., 2018. Virtualna realnist: vid tekhnolohii do mystetstva. Mystetstvoznavchi zapysky, 34, pp.112-122.

Nosov, N.A., 2000. Virtualnaia psikhologiia [Virtual psychology]. Moscow: Agraf.

Ribo, T., 1901. Tvorcheskoe voobrazhenie [Creative imagination]. [online] St. Petersburg: Tipografiia lu.N. Erlikh. Available at: <https://biblioclub.ru/index.php?page=book\&id=228207> [Accessed 02 April 2021]. 


\title{
ВІРТУАЛЬНИЙ ПРОДАКШН: НОВИЙ ПІДХІД ДО КІНОВИРОБНИЦТВА
}

\author{
Олександр Прядкоㅁ, Максим Сіренко2а \\ ${ }^{1}$ заслужений працівник культури України, кандидат технічних наук, доцент; \\ e-mail: globalfilm2017@gmail.com; ORCID: 0000-0002-9080-6758 \\ ${ }^{2}$ магістрант кафедри кіно-, телемистецтва; \\ e-mail: maksym.sirenko99@gmail.com; ORCID: 0000-0003-0384-368X

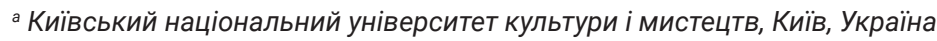

\section{Анотація}

Мета дослідження - дослідити складові віртуального виробництва. Визначити структуру, основні інструменти віртуальних технологій та їх переваги. Встановити відмінності між віртуальними процесами та традиційним кіновиробництвом. Методологія дослідження базується на загальнонаукових методах комплексного аналізу процесів, які відбуваються у віртуальному виробництві, та аналізу основних віртуальних інструментів, комп'ютерних програм; використанні порівняльного методу віртуального виробництва з традиційною технологією кіновиробництва; узагальненні способу дії віртуальних технологій, визначенні їх переваг і недоліків, дослідженні їх впливу на сучасне кіномистецтво. Наукова новизна одержаних результатів полягає в системному аналізі складових та інструментів сучасних віртуальних технологій. Визначено особливості віртуального виробництва та його вплив на кіноіндустрію, доведено актуальність та раціональність застосування віртуальних технологій як сьогодні, так і у майбутньому. Висновки. В процесі дослідження були виявлені численні переваги та нові можливості, які пропонує віртуальне виробництво. Проаналізовано сутність віртуальних процесів в кіновиробництві, показано як сучасні комп'ютерні інструменти можна творчо застосовувати на кожному етапі кіновиробництва. Віртуальне виробництво - це наступний логічний крок у постійній еволюції кіномистецтва, який змінює кіноіндустрію вже сьогодні.

Ключові слова: віртуальне кіновиробництво; фільм; технологія; препродакшн; візуалізація; кіномистецтво; візуальні ефекти; доповнена реальність 


\title{
ВИРТУАЛЬНЫЙ ПРОДАКШН: НОВЫЙ ПОДХОД К КИНОПРОИЗВОДСТвУ
}

\author{
Александр Прядко1а, Максим Сиренкоª \\ ${ }^{1}$ заслуженный работник культуры Украины, кандидат технических наук, доцент; \\ e-mail: globalfilm2017@gmail.com; ORCID: 0000-0002-9080-6758 \\ 2 магистрант кафедры кино-, телеискусства; \\ e-mail: maksym.sirenko99@gmail.com; ORCID: 0000-0003-0384-368X \\ а Киевский национальный университет культуры и искусств, Киев, Украина
}

\begin{abstract}
Аннотация
Цель исследования - исследовать составляющие виртуального производства. Определить структуру, основные инструменты виртуальных технологий и их преимущества. Установить различия между виртуальными процессами и традиционным кинопроизводством. Методология исследования базируется на общенаучных методах комплексного анализа процессов, происходящих в виртуальном производстве, и анализа основных виртуальных инструментов, компьютерных программ; использовании сравнительного метода виртуального производства с традиционной технологией кинопроизводства; обобщении образа действия виртуальных технологий, определении их преимуществ и недостатков, исследовании их влияния на современное киноискусство. Научная новизна исследования заключается в системном анализе составляющих и инструментов современных виртуальных технологий. Определены особенности виртуального производства и его влияние на киноиндустрию, доказана актуальность и рациональность применения виртуальных технологий как сегодня, так и в будущем. Выводы. В процессе исследования были выявлены многочисленные преимущества и новые возможности, которые предлагает виртуальное производство. Проанализирована сущность виртуальных процессов в кинопроизводстве, показано как современные компьютерные инструменты можно творчески применять на каждом этапе кинопроизводства. Виртуальное производство - это следующий логический шаг в постоянной эволюции киноискусства, который меняет киноиндустрию уже сегодня. Ключевые слова: виртуальное кинопроизводство; фильм; технология; препродакшн; визуализация; киноискусство; визуальные эффекты; дополненная реальность
\end{abstract}

